\title{
Social inequality and the SARS-CoV-2 in Brazil: How prepared are Brazil's municipalities in health infrastructure to tackle the disease?
}

\begin{abstract}
The emergence of new diseases such as SARS-CoV-2 is a reflection of the expansion of anthropic activities on natural ecosystems. The first case in Brazil was reported in February and the number of confirmed cases and the death rate is increasing at an alarming rate. In this context, this study aims to answer two main questions: is social inequality related to SARS-CoV-2 confirmed cases and death rate and how distributed is the health infrastructure in Brazil to tackle the SARSCoV-2 disease, relating directly to the third UN's Sustainable Development Goal, Good Health and Well-being. To this purpose, the researchers applied the Moran's Bivariate Local Spatial Autocorrelation Index to assess the relationship between Gini coefficient with confirmed SARS-CoV-2 cases and the death rate of the disease and the Global Moran Index to assess the distribution of health infrastructure to tackle the disease. We focused on obtaining results that allow decision-making in the health and government sectors. The results display an imbalance between demand and supply, with precarious health infrastructure for people with severe symptoms and increased deaths. SARS-CoV-2 is spreading fast throughout Brazil, and the north and northeast region need special attention due to its lack of health infrastructure. Cartographic products are essential to decision making in epidemiological studies.
\end{abstract}

Keywords: Coronavirus; SARS-CoV-2; Health management; Epidemic; Spatial autocorrelation.

\section{Desigualdade social e SARS-CoV-2 no Brasil: quão preparados estão os municípios brasileiros em infraestrutura de saúde para enfrentar a doença?} O surgimento de novas doenças como o SARS-CoV-2 é reflexo da expansão das atividades antrópicas nos ecossistemas naturais. O primeiro caso no Brasil foi
notificado em fevereiro e o número de casos confirmados e a taxa de mortalidade estão aumentando em ritmo alarmante. Nesse contexto, este estudo visa
responder a duas questões principais: qual é a desigualdade social relacionada aos casos confirmados e taxa de mortalidade por SARS-CoV-2 e qual a distribuição
da infraestrutura de saúde no Brasil para o enfrentamento da doença por SARS-CoV-2, relacionando-se diretamente à o terceiro Objetivo de Desenvolvimento
Sustentável da ONU, Boa Saúde e Bem-estar. Para isso, os pesquisadores aplicaram o Índice de Autocorrelação Espacial Local Bivariada de Moran para avaliar a
relação entre o coeficiente de Gini com casos confirmados de SARS-CoV-2 e a taxa de mortalidade da doença e o Índice de Moran Global para avaliar a distribuição
da infraestrutura de saúde para enfrentar a doença. Focamos na obtenção de resultados que possibilitem a tomada de decisões nos setores de saúde e governo.
Os resultados mostram um desequilíbrio entre demanda e oferta, com infraestrutura de saúde precária para pessoas com sintomas graves e aumento de óbitos.
O SARS-CoV-2 está se espalhando rapidamente por todo o Brasil, e as regiões norte e nordeste precisam de atenção especial devido à falta de infraestrutura de
saúde. Os produtos cartográficos são essenciais para a tomada de decisão em estudos epidemiológicos.

Palavras-chave: Coronavírus; SARS-CoV-2; Gestão de saúde; Epidemia; Autocorrelação espacial.

Topic: Planejamento, Gestão e Políticas Públicas Ambientais

Reviewed anonymously in the process of blind peer.
Received: 04/06/2021

Approved: 29/06/2021
Rodrigo Martins Moreira

Universidade Federal de Rondônia, Brasil http://lattes.cnpq.br/5667113061834775 rodrigo.moreira@unir.br

Alejandra Carolina Villa Montoya (if Antioquia Institute of Technology, Colômbia http://lattes.cnpq.br/0519704905202769 http://orcid.org/0000-0001-8872-7439 acvillamontoya@gmail.com

Sara Line Silveira Araujo (ib

Universidade Federal de Rondônia, Brasil http://lattes.cnpq.br/9350449763801243 http://orcid.org/0000-0002-3615-7216 araujoline0@gmail.com

DOI: 10.6008/CBPC2179-6858.2021.006.0054

\begin{abstract}
Rafaela Aparecida Trindade (iD)
Universidade Federal de Rondônia, Brasil http://lattes.cnpq.br/9972103991977069 http://orcid.org/0000-0002-7473-6374 rafaelaelaatrindade1@gmail.com

Dara da Cunha Oliveira (1D)

Universidade Federal de Rondônia, Brasil http://lattes.cnpq.br/1862966760153808 http://orcid.org/0000-0002-6142-8110 oliveiradara216@gmail.com

Guilherme de Oliveira Marinho

Universidade Federal de Rondônia, Brasil http://lattes.cnpq.br/8394496735507914

Guimarinho.amb.san@gmail.com
\end{abstract}

Referencing this:

MARTINS, R. M.; MONTOYA, A. C. V.; ARAUJO, S. L. S.; TRINDADE, R. A.; OLIVEIRA, D. C.; MARINHO, G. O.. Social inequality and the SARSCoV-2 in Brazil: How prepared are Brazil's municipalities in health infrastructure to tackle the disease?. Revista Ibero Americana de Ciências Ambientais, v.12, n.6, p.651-664, 2021. DOI: http://doi.org/10.6008/CBPC2179-6858.2021.006.0054 


\section{INTRODUCTION}

Public health is sensitive to changes in unbalanced relations between the environment, pathogens and communities. Any changes in this relationship can trigger the activation of new infectious agents or the resurgence of neglected diseases, which can result in serious consequences for health at a local and global scale (JIMÉNEZ, 2013). This work directly relates to the third Sustainable Development Goal, Good Health and Well-being. It is of paramount importance to develop research assessing the relationship between social indicators, such as social inequality and health infrastructure. The adequate allocation of technology and health services can aid to mitigate the risks related to the pandemic (ELAVARASAN et al., 2020).

At the end of 2019, a new coronavirus was discovered in Wuhan, China, that infected humans, called SARS-CoV-2, causes SARS-CoV-2 disease and Severe Acute Respiratory Syndrome (SARS). Complications range from respiratory infections to septic shock, with patients requiring intensive care and a mortality rate of $\sim 10 \%$ (SAHIN et al., 2020). The occurrence of the spring festival in Wuhan, led to a high flow of travelers in the city, which favored the spread of the new coronavirus to other countries, with a statistic of 215 countries with the presence of SARS-CoV-2, 44,351,506 infected and 1,171,255 deaths globally until 27 October. In Brazil, there were a total of 5,469,755 confirmed cases for SARS-CoV-2 until October 27, 2020, with a progressive increase in confirmed cases due to the presence of airports and seaports with international and national destinations, which allowed dispersion throughout the national territory.

The most common transmission route between humans corresponds to contact with saliva that contains the pathogen. The ease of transmission and contamination capacity by asymptomatic people during virus incubation (from 2 to 10 days) allow SARS-CoV-2 to be highly contagious, risking the health of a high number of people (LI et al., 2020; ROTHE et al., 2020; SAHIN et al., 2020). Consequence of RNA-like genetic material, high rate of recombination and errors in transcription, great mutability of this type of virus has been observed, a characteristic that allows its presence in a wide variety of animal and human guests (SAHIN et al., 2020). The possibility of mutation allows us to think about the potential of observing new varieties and epidemics of this virus in the future, which makes it necessary to develop research in this field (SAHIN et al., 2020).

Studies indicate that SARS-CoV-2 can cause symptoms such as fever, cough, shortness of breath, and fatigue, and in some cases diarrhea, chest pain, nausea, vomiting, headache, hemoptysis and sputum (CHEN et al., 2020; PAN et al., 2020). Currently, an antiviral or vaccine against SARS-CoV-2 has not been development, which is why symptoms such as fever or cough are mainly treated, and in the case of severe respiratory infection, difficulty breathing or hypoxemia, therapy with oxygen and/or antibiotics (SOHRABI et al., 2020). To treat the hospitalized patients, some infrastructure is mandatory, such as pulmonary ventilators, pulmonary resuscitators and hospital beds. However, the best way to control SARS-CoV-2 is through preventive actions that reduce its transmission, such as good hygiene practices and quarantine, low cost and highly effective measures against contagion, with a lower economic and social impact (MCKIBBIN et al., 2020). 
Studies have verified the social inequality and its relationship with COVID-19 per state with an important effect on the deaths and confirmed cases, since each location presents different biological, social and economic disadvantages in addition to adoption of health policies to overcome the pandemic. But there is still a gap regarding analysis on a municipal scale, which this paper seeks to fill. The social inequality situation is mitigated due to the public universal access to the health system (Sistema Único de Saúde), but regardless of the SUS being of public access, the socioeconomic vulnerable population still face major threats by the COVID-19 (DEMENECH et al., 2020; GARCIA et al., 2020). For example, Barreto et al. (2020) observed social inequality in terms of access to sanitation and water, agglomeration conditions and the presence of chronic diseases in Brazil, making necessary the expansion of the hospital structure to tackle the pandemic (BARRETO et al., 2020) and greater governmental concern (GARCIA et al., 2020), in places with a lower socioeconomic level. To the researchers' knowledge, to the moment this paper was written, no work has explored the relationship between social inequality, using the Gini coefficient, and key hospital infrastructure to tackle the COVID-19, such as hospital beds and lung ventilators and reanimators.

In this context, due to globalization, outbreaks of local viral diseases are able to spread to other territories in a matter of days, generating pandemics. In the current scenario, SARS-CoV-2 is a challenge for the health systems and economy of Brazil, with concern regarding the availability of intensive care units and specific diagnostic tests (RODRIGUEZ-MORALES et al., 2020). Thus, spatial analyses of dissemination and sociological and demographic aspects, as well as mapping of infrastructure for emergency responses are key. Geographic databases elaborated on Geographic Information Systems (GIS) platforms translate into response tools, free of charge and capable of analyzing large areas in a short period. When Moran index is applied with GIS, it is possible to estimate georeferenced health outcomes for target areas in different scales, identify clusters of the hardest hit areas, locations with the low response capacity from the health system due to low availability of beds, pulmonary resuscitators and ventilators (CORDES et al., 2020; TRUONG et al., 2019). For example in the research of Campos et al., (2021) analyzed sustainability from environmental quality, economic prosperity and social justice in municipalities and in the state of Rio Grande do Sul, and the Moran Index was useful for identifying clusters of municipalities that needed urgent effective intervention and those that could be improved.

This work is led by two main research questions: is social inequality related to SARS-CoV-2 confirmed cases and death rate and how distributed is the health infrastructure in Brazil to tackle the SARS-CoV-2 disease. To this purpose, the researchers applied the Moran's Bivariate Local Spatial Autocorrelation Index to assess the relationship between Gini coefficient with confirmed SARS-CoV-2 cases and the death rate of the disease and the Global Moran Index to assess the distribution of health infrastructure to tackle the disease. This article innovates by presenting how GIS can assist in preventive, emergency and pandemic management processes by integrating key social, health infrastructure and pandemic data with GIS. These results are key to decision making regarding the allocation of operational and human resources by researchers, government agencies and professionals. Therefore, this study can be replicated for different countries that have similar databases. This work is key to decision-makers in the field of healthcare and to 
focus efforts and investments in strategic locations.

\section{MATERIALS AND METHODS}

\section{Study area}

Brazil (Fig. 1), is the fifth largest country in territorial extension $(8,510,820.623$ square $\mathrm{km})$, and is divided into 26 states and one Federal District, which results in 5,570 municipalities throughout Brazil. It is estimated that there are 210.1 million inhabitants with a population growth rate equivalent to $0.79 \%$ per year. Based on cultural, economic, social and natural criteria, the Brazilian territory is divided into 5 regions, as shown in Figure 1, namely: North, Midwest, Northeast, Southeast and South. We have gathered confirmed cases from each municipality from the Brazil.io Platform (2020). We used the Inverse Distance Weighting (BARTIER et al., 1996) to interpolate the municipal data.

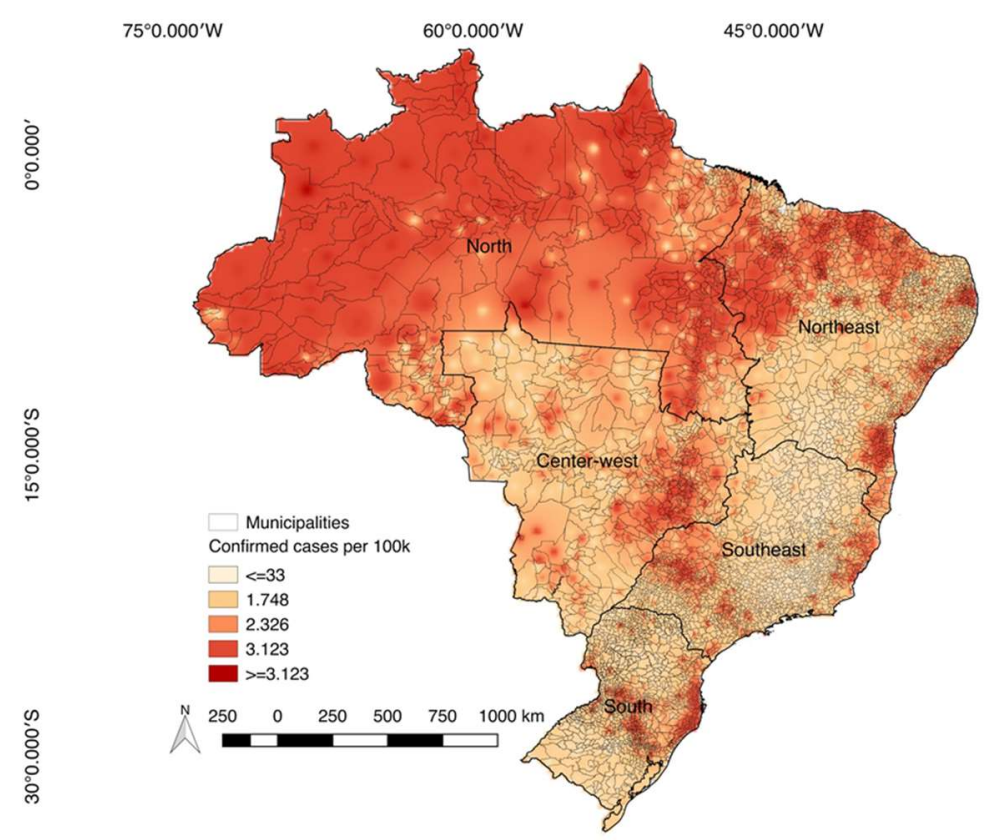

Fig. 1: SARS-CoV-2 confirmed cases in Brazil from February $1^{\text {st }}$ to October $27^{\text {th }}, 2020$.

\section{General workflow}

This study was developed in several stages, which are shown in Figure 2.

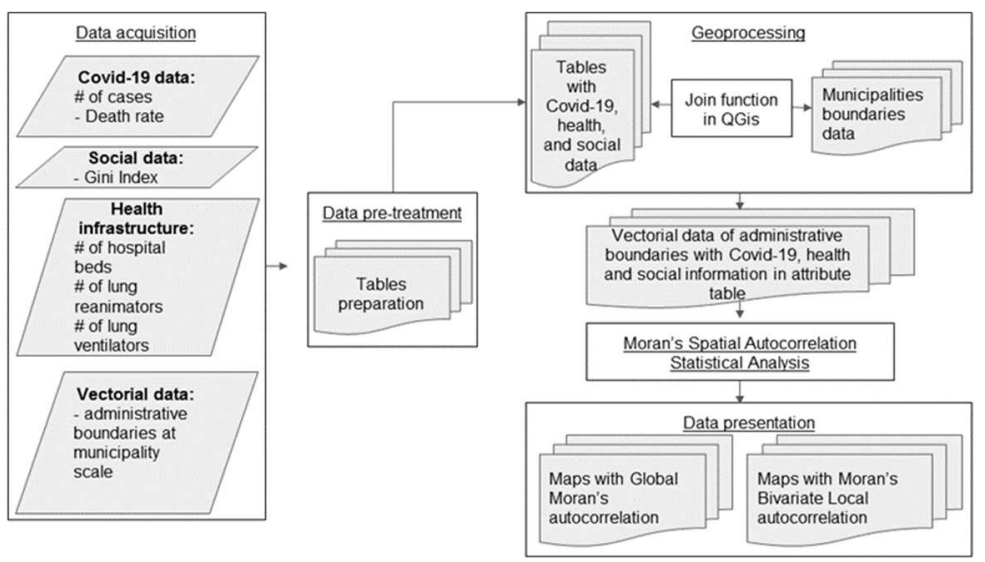

Fig. 2: General workflow with research steps. 


\section{Data acquisition}

Data for monitoring confirmed cases and death rate of SARS-CoV-2, number of hospital beds, number of ventilators and number of pulmonary resuscitators were acquired using the Brazilian Ministry of Health's Tabnet DataSUS platform. The Gini coefficient represents the inequality of a certain place and can be used in different scales, its values range from 0 to 1 , where the closest to 1 the higher the inequality. In this work it is used on a municipal scale.

\section{Pre-processing of data}

For data entry in the geoprocessing software, tables needed to be prepared. First, we evaluated the consistency and accuracy of the data obtained. Subsequently we prepared the relationship column between the table with health data and the table of attributes of vectorial data.

\section{Geoprocessing}

The geoprocessing platform used was QGis, version 3.4, which is a free and open source software. The data on medical infrastructure was integrated into the table of attributes of vectorial data through the join function of the software. The statistical analyses of Spatial Autocorrelation of the Moran Index were performed using the TerraView and GeoDa softwares.

\section{Moran's spatial autocorrelation analysis}

\section{Moran's Bivariate Local Spatial Autocorrelation}

The interaction between Statistics and Geographic Information Systems enables analysis of numerous georeferenced variables and gives rise to Area Spatial Statistics. In this branch, it is possible to describe and analyze processes that occur in the geographical space, making use of geographical references, vector files, description and data analysis (ANSELIN, 1995; 2010).

In this context, the Moran Bivariate Local Spatial Correlation Index suggests a local autocorrelation indicator, which makes use of the spatial covariance between polygons to explore the level of dependence. It relates closely to its global counterpart by capturing the relationship between a variable's value at location $i, x_{i}$, and the average of the neighbor's values for another variable, the product being $x_{i}$ with the spatial lag of $z_{i}$. In this work it was used as the first order queen contiguity weight matrix. This in turn produces a diagram that allows examining the linear relationship between two variables, making it possible to analyze the distribution in four quadrants, namely: "high-high (HH), low-low (LL), high-low (HL) and low-high (LH)" The Local Moran is described in eq. 1 and Moran's Bivariate Local Spatial Autocorrelation is calculated using equation 2 (ANSELIN, 1995; 2010; 1996).

$$
I_{i}=\left(\frac{z_{i}}{m 2}\right) \sum_{j} \quad w_{i j} z_{j} \quad \text { eq. } 1
$$

Where $I_{i}$ is the Local Moran's, $m_{2}=\sum_{i} \quad z_{i}^{2}$ does not vary with $i$, and $w_{i j}$ represents the elements of the spatial weight's matrix. 


$$
I_{B, i}=c x_{i} \sum_{j} \quad w_{i j} z_{j} \quad \text { eq. } 2
$$

Where $I_{B, i}$ is the Bivariate Local Moran's, and $w_{i j}$ represents the elements of the spatial weight's matrix.

The graphic representation of this method can be observed in the dispersion diagram that allows us to identify clusters. This is an important tool that aims to identify the general association by the linear correlation between the variable $x_{i}$ and $z_{i}$ at each spatial unit. The first quadrant $(\mathrm{HH})$ indicates regions with high values for the analyzed variables surrounded by regions that also present average high values; the second quadrant (LL) represents that the variable and its neighboring values are low; the third quadrant (HL) indicates a high variable value with neighbors with low values; and the fourth quadrant (LH) illustrates variables with low values with neighbors with high values (ANSELIN, 1995; 2010; 1996).

\section{Moran's Global Spatial Autocorrelation Index}

As a means of incorporating, in the best way, the notion of spatial contiguity in an autocorrelation measure, we sought to capture the spatial association between the location pairs, which are the areas, and for this purpose, the spatial structure matrix was used.

Once the spatial structure matrix was determined, the individual degree of self-correlation is constituted by defining a way to estimate the dissimilarity between attribute values related to areas through the Global Moran Index (I) (CÂMARA et al., 2004). That from autocorrelation, considering only its first neighbor, is obtained by:

$$
I=\frac{\sum_{i}^{n}=1 \sum_{i}^{n}=1 w_{i j}\left(z_{i}-\mu_{z}\right)\left(z_{j}-\mu_{z}\right)}{\sum_{i}^{n}=1\left(z_{i}-\mu_{z}\right)^{2}} \quad \text { eq. } 3
$$

Where $\eta$ - the number of areas; $z_{1}$ - value of the attribute considered in area $i ; z$ - mean value of attribute in the studied region; $\mathrm{w}_{\mathrm{ij}}$ - the elements of the normalized matrix of spatial proximity. Spatial independence is understood as $\mathrm{HO}$, where its value is equal to zero.

In order to verify the existence of similarity between normalized values in each area, and the mean of its neighbors, the object of the Moran diagram was used. It is worth mentioning that the diagram is constituted based on the original values that are subtracted from the global mean value, and thus divided by the standard deviation

Spearman's rank correlation coefficients (SRCC) between deaths/confirmed cases per COVID-19 and health infrastructure and Gini coefficient were analyzed. A correlation between two variables was considered statistically robust if the SRCC $\geq 0.6$ or $\leq-0.6$ and the $p$-value $\leq 0.05$. Statistical analyses were performed on PAST (PAleontological Statistics) version 2.17.

\section{RESULTS AND DISCUSSION}

\section{Big data and GIS integration: Creating geographic databases using information from the Ministry of Health}

In a world pandemic scenario, such as the one installed in recent months by SARS-CoV-2, technological tools to support decision-making are essential. In the fight against this pandemic, the spatialization of information has been key to the management of human and hospital resources, as well as the identification of trends and patterns of disease dissemination. The integration between GIS and Big 
Data allows the development of cartographic materials for monitoring and dissemination routes of the epidemic in a short period, identification of dissemination epicenters, allocation of human and operational resources, identification of risk levels and control and emergency measures, formulation and evaluation of the effectiveness of control and emergency measures, and spatial information with technical-scientific rigor to support decision-making (ZHOU et al., 2020).

In this sense, the integration between GIS and Big Data, such as the information provided by the Brazilian Ministry of Health, allows the creation of geographic databases (GDB). In this study, we sought to map hospital resources for emergency responses to the demands generated by the pandemic at the level of Brazil. Also, the GDB allowed the crossing of information and identification of epicenters of disease transmission and factors that can be related to this cause and effect.

However, for the creation and continuous supply of these databases, reliable data regarding their quality and frequency are necessary. Decision making for the prevention and control of epidemics depends directly on the robustness of spatial information. Spatialization of big data related to epidemics allows the rapid mapping of their spatio-temporal behavior, supporting the development of prevention, control and monitoring strategies for cases and medical resources, ensuring efficiency in management processes (ZHOU et al., 2020). Thus, the responsibility to present data in a standardized way, following the methodological assumptions of cartography, is extremely important. In the present study, we chose to use the choropleth method for cartographic representation of specialized health and infrastructure information.

\section{Spatial distribution of confirmed cases for SARS-CoV-2}

Until October 28, 2020, southeast region was the most affected region, with 1916,569 confirmed cases, the state of São Paulo was leading the number of confirmed SARS-CoV-2 cases, with approximately 374,604 infected people, and Rio de Janeiro a total of 132,044. The October 28, 2020 update showed that São Paulo continued to lead the number of cases $(1,103,582)$ being followed by the state of Minas Gerais $(353,311)$, Bahia $(349,711)$ and then Rio de Janeiro $(306,672)$. The result matches the location of the beginning of detection of the virus in the country, since the first confirmed case was observed on March 2 , 2020 in São Paulo, the largest metropolitan center in the southern hemisphere (ROCHA FILHO et al., 2020). According to Augusta et al. (2018) an epidemic affects multiple regions at once, therefore, all regions must be created for control activities and avoiding the disease spread (AUGUSTA et al., 2018).

These results are similar to those observed by Cuadros et al. (2020) during the study of spatiotemporal transmission of COVID-19 in Ohio, U.S. The author verified more impact of the disease in cities with superior population and airport connection (274 cases per 100,000 people), similar conditions observed in the southeast region (CUADROS et al., 2020). The conclusion of the study was that these regions need superior capacity of the healthcare system, mainly intensive care units (ICU) and beds, to allow overcoming the virus transmission and further treatment of infected patients. 


\section{Moran's Bivariate Local Spatial Autocorrelation}

The Moran's Bivariate Spatial Autocorrelation method allows one to map the probability statistic significant values of the measure. In this work, we compared the variables Gini coefficient, that is a measure of social inequality, with the lagged variables confirmed cases of SARS-CoV-2 and the death rate of SARSCoV-2 in a municipal scale. The application of this method contributes to the visualization of the results, since it enables the mapping of values and facilitates the analysis of management parameters and local needs.

Figure 3 displays the major concentration of $\mathrm{HH}$ clusters, municipalities with high values of the Gini coefficient (high social inequality) and high number of confirmed cases for the neighboring municipalities. In the south and southeast regions, the figure displays LL clusters, with low values of the Gini coefficient (low social inequality) and low values of confirmed cases for the neighboring municipalities. In the northeast region it is noticed $\mathrm{HL}$ clusters with high values of the Gini coefficient and low values for confirmed cases in the surrounding neighborhood.

Figure 4 presents $\mathrm{HH}$ clusters, municipalities with high values of the Gini coefficient and high level of death rates for the neighboring municipalities. In the south and southeast regions, the figure displays LL clusters, with low values of the Gini coefficient (low social inequality) and low values of death rate for the neighboring municipalities. In the northeast region it is noticed HL clusters with high values of the Gini coefficient and low values for death rate in the surrounding neighborhood. These results corroborate with Oliveira et al. (2020), regarding the susceptibility of vulnerable communities to the SARS-CoV-19 disease.

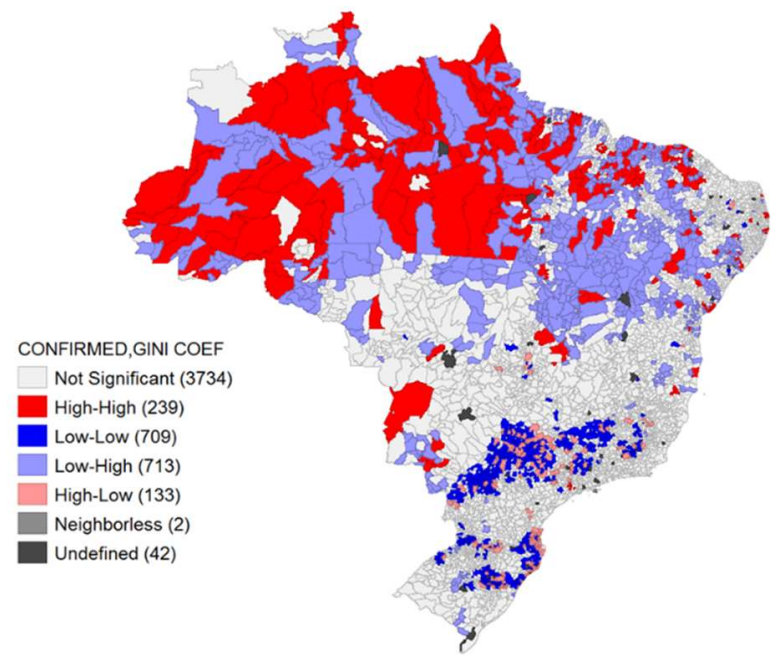

Fig. 3: Spatial autocorrelation for confirmed cases and Gini coefficient from February $1^{\text {st }}, 2020$ to October $27^{\text {th }}$, 2020.

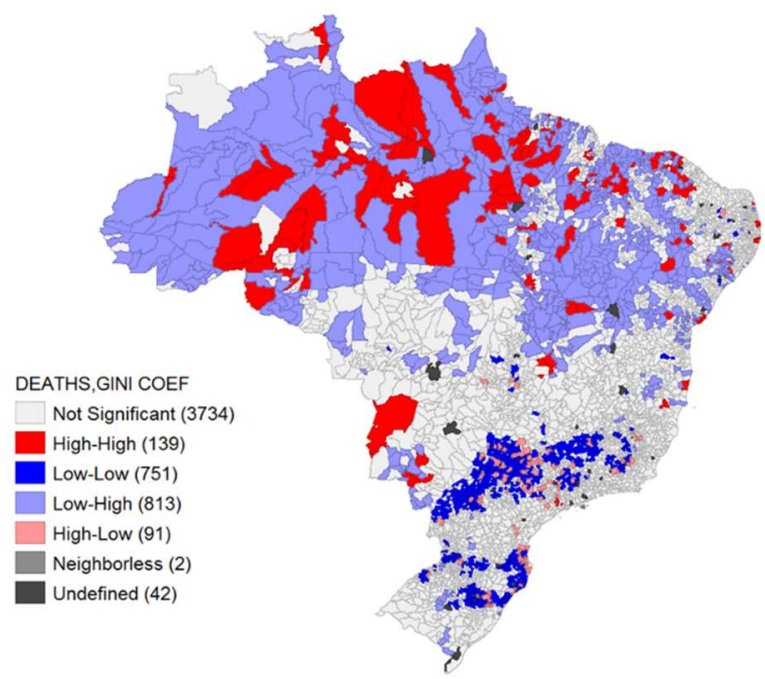

Fig. 4: Spatial autocorrelation for death rate and Gini coefficient from February $1^{\text {st }}, 2020$ to October $27^{\text {th }}$, 2020.

The reason for the south and southeast regions present such results is due to belonging to a renowned industrial complex in the country. Visconti and Santos (2016) portrays the financial influence that south and southeast regions has on the country, which accounts for about $44 \%$ of the population and $49.5 \%$ of the national Gross Domestic Product (GDP), as well as the largest number of companies (VISCONTI et al., 2015). As a consequence of these activities, the urbanization process is accentuated in the southeast region, 
explaining the accelerated population growth of São Paulo (SALDIVA, 2018). However, the rapid expansion of the virus in a few days becomes a concern due to the fragility of the health system in this region (RODRIGUEZ-MORALES et al., 2020).

Brazil has a low availability of tests to determine the virus, a situation that underestimates the growth curve of confirmed cases for SARS-CoV-2 and precludes making adequate containment decisions (MATTOS et al., 2020). Citing Figueiredo et al. (2020), one of the strategies used by countries with better responses to the pandemic, such as South Korea, was SARS-CoV-2 mass testing, which allowed to formulate appropriate policies, with lower economic and social impacts (FIGUEIREDO et al., 2020).

The identification of the incidence and spread of the new coronavirus in the Brazilian territory through geoprocessing simultaneously favors the provision of services in the health area. Once places that require more surveillance and control are identified, it is possible to minimize the effects and avoid possible occurrences in the future. Preventive measures should be taken in the region where there is a greater occurrence, in order to remedy impacts, as well as in the least affected areas, so that the spread of the virus is curbed.

\section{Moran's Global Spatial Autocorrelation}

Moran Map is an effective tool in the socioeconomic visualization of regions, one that is able to link the other external variables, visions and behavioral knowledge of these when comparing their groupings and characteristics, to increase the possibility of dynamic understanding of the data, and to contribute to the basis of explanatory hypotheses (MARQUES, 2018). In this way, Figure 5 allows comparing the behavior of regions regarding Gini coefficient.

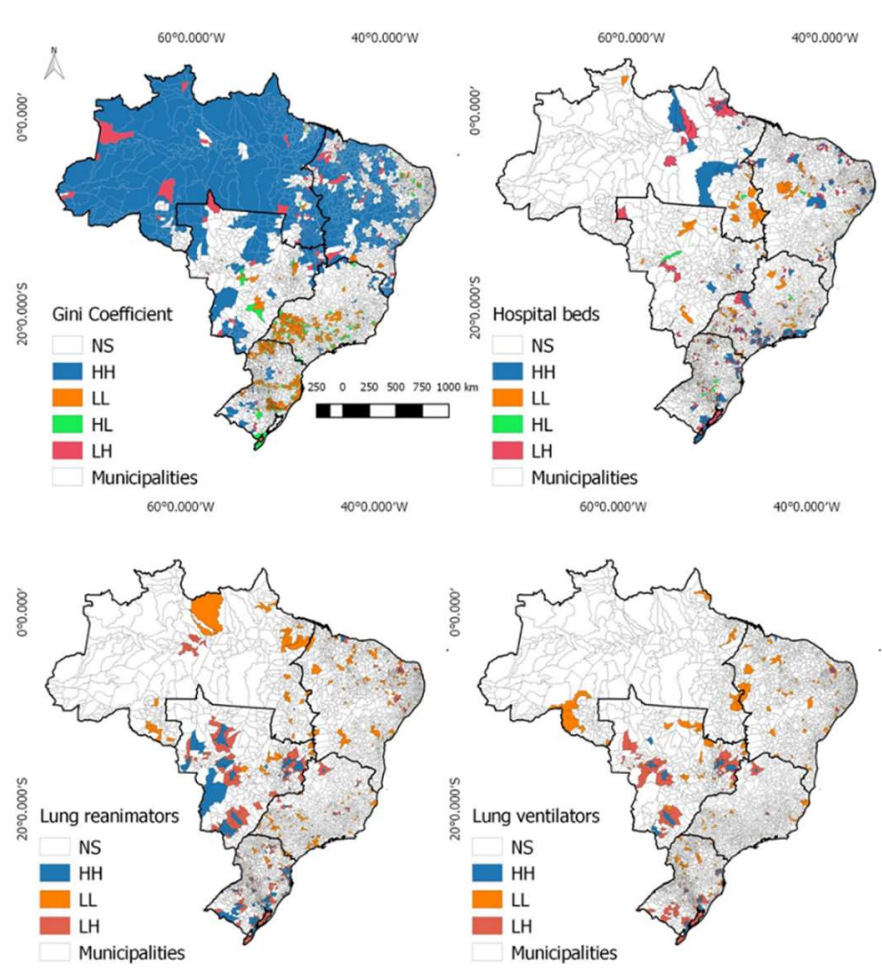

Fig. 5: Spatial distribution of Gini coefficient (top left panel), hospital beds (top right panel), lung resuscitators (bottom left panel) and lung ventilators (bottom right panel) for Brazilian municipalities. 
For the Gini coefficient variable in figure 3 (top left panel), the value for the Global Moran Index was $0.45(\mathrm{P}<0.01)$, with $18 \%$ of municipalities presenting $\mathrm{HH}$ values, which means municipalities with high social inequality with neighbors with high social inequality, $13 \%$ with LL values, municipalities with low social inequality surrounded by municipalities with low social inequality, $2 \%$ with $\mathrm{HL}$ values, where high social inequality municipalities were surrounded by low social inequality neighbors and $1.5 \%$ with LH values, where low social inequality municipalities where surrounded by high inequality municipalities.

The Gini coefficient evidenced inequality between regions and municipalities, with risk cluster areas in the south and southwest region. This is an important aspect to consider because the population in areas with high poverty. $\mathrm{HH}$ clusters showed different demography or infectious disease incidences in spatial epidemiology (TRUONG et al., 2019). Areas with higher inequalities may be useful in guiding policy and health system efforts and planning the adequate responses to SARS-CoV-2 as the pandemic (CORDES et al., 2020). For example, Cordes and Castro (2020) observed that SARS-CoV-2 may result in an exacerbation of existing inequalities, evidencing that high-density cities and African Americans population are more susceptive to infection and mortality in New York city. due to unproportioned access to job and medical care (CORDES et al., 2020).

In other study, it was identified geographical disparities of COVID-19 in Ohio (U.S), due to differences in socioeconomic level, air pollution, comorbidities, beds and ICU capacity, affecting directly the disease dynamic and intervention, for example with faster saturation of healthcare infrastructure in areas with high population density (CUADROS et al., 2020). In addition, the HH areas in north and northwest may put neighborhoods at greater health risk and greater economic risk due to the socioeconomic characteristics, which increase the course of the pandemic. In this context the community cohesion is very important, mainly during isolation period, allowing the recuperation of these regions where the COVID-19 had higher impact (ROSENKRANTZ et al., 2020).

SARS-CoV-2 symptoms are varied, but part of the infected population needs hospital care. The gradual increase in confirmed cases in a short period suggests the need to supply health centers with personal protective equipment, beds, pulmonary resuscitators and ventilators, medications and other materials and equipment necessary for hospitalization, care and treatment of patients with more serious symptoms, justifying the need to map the spatial distribution of these key equipments to treat COVID-19 patients.

Figure 3 (top right panel) shows the spatial autocorrelation of hospital beds in Brazil, presented values for the Global Moran Index of 0.18 ( $p>0.01$ ), presenting $4 \%$ of municipalities with $\mathrm{HH}$ values, $4.5 \%$ presenting LL values, $0.25 \%$ presenting HL values and $4.7 \%$ with LH values. Mattos et al. (2020) estimates that of the $20 \%$ of the population infected with SARS-CoV-2, $5 \%$ needed intensive therapy for 5 day. From this scenario, it is assumed that of the $\sim 2,113,749$ people sick with SARS-CoV- 2 in Brazil, $\sim 422,750$ will need hospital beds. In this context, the decrease in the speed of contagion is the recommendation to increase the capacity of making beds available to sick people. For the southeastern region, there are between 7,929 and 90,603 beds, most of them in São Paulo. Under current conditions, critically ill people can be hospitalized, but the exponential growth behavior of positive cases makes it necessary to develop strategies to reduce the 
speed of virus propagation.

In this scenario, respiratory equipment is key for treating the SARS-CoV-2 patients. The spatial autocorrelation for lung resuscitators presented Global Moran Index value of 0.18 ( $p>0.01$ ) with $2.47 \%$ of municipalities with $\mathrm{HH}$ values, $4.8 \%$ of municipalities with LH values. The majority of LL values are clustered in the northeast region, as shown in figure 3 (bottom left panel). The spatial autocorrelation for lung ventilators presented Global Moran Index values of 0.09 ( $p>0.01$ ), presented $0.68 \%$ of municipalities with $\mathrm{HH}$ values, 3.2\% of municipalities presented LL values and $2.9 \%$ presented LH values. HH Clusters can be noticed in southeast regions. Northeast and North regions have a majority of municipalities with LL values as shown in figure 3 (bottom right panel). Brazil has a total of 65,411 lung ventilators and 138,080 lung resuscitators, respectively. Following the calculation suggested by the data by Mattos et al. (2020), $\sim 48,616$ people will need these equipment. North and northwest are regions with low availability of pulmonary equipment, must be taken into account, since people without access to treatment with pulmonary equipment are potentially fatal cases, which presupposes a worrying scenario.

In cases where the virus leads to a high degree of infection, patients may need intensive care with the use of ventilators or pulmonary resuscitators. This is because in the reproduction cycle of SARS-CoV-2, the release of new viruses occurs through exocytosis, destroying the cells of the pulmonary tissues (SAHIN et al., 2020). The most vulnerable population are men over 50 and with cardiovascular, cerebrovascular, digestive and endocrine problems, in which the disease can lead to fatal outcomes and acute respiratory failure (CHEN et al., 2020; MACEDO et al., 2020).

In this context, more research using GIS are of paramount importance in Brazil, even after the peak of the pandemic, to control outbreaks of the virus. This because isolation and social withdrawal is a strategy with severe impacts in the economic sector, that it is not possible applied by long time, for which the spatial analysis of the pandemic can subsidies strategic efforts for economic sustainability (ROSENKRANTZ et al., 2020).

\section{Gini, health infrastructure and confirmed/deaths cases correlation}

Correlations between total confirmed cases and deaths with key hospital equipment, such as pulmonary resuscitators and ventilators, hospital beds and the Gini coefficient were investigated, in a State scale, by calculating their Spearman\&\#39;s rank correlation coefficients (SRCC, Fig. 6). Number of total confirmed and deaths cases by COVID-19 had significant positive correlations with the total ventilators and hospital beds, displayed in table 1.

Table 1: Input values for the Spearman's rank correlation coefficient.

\begin{tabular}{lllll}
\hline State & Hospital beds & Lung resuscitators & Lung ventilators & Gini coefficient \\
\hline Acre & 1,581 & 64 & 32 & 0.6394 \\
\hline Alagoas & 5,591 & 99 & 60 & 0.6343 \\
\hline Amapá & 1,132 & 32 & 18 & 0.6157 \\
\hline Amazonas & 5,126 & 193 & 117 & 0.6664 \\
\hline Bahia & 24,086 & 1.010 & 552 & 0.6278 \\
\hline Ceará & 15,399 & 613 & 244 & 0.6193 \\
\hline Distrito Federal & 4,554 & 154 & 65 & 0.637 \\
\hline
\end{tabular}




\begin{tabular}{|c|c|c|c|c|}
\hline Espírito Santo & 5,253 & 273 & 117 & 0.5723 \\
\hline Goiás & 11,287 & 466 & 298 & 0.5588 \\
\hline Maranhão & 13,365 & 324 & 166 & 0.6291 \\
\hline Mato Grosso & 5,491 & 349 & 163 & 0.5652 \\
\hline Mato Grosso do Sul & 3,938 & 221 & 83 & 0.565 \\
\hline Minas Gerais & 29,603 & 2.035 & 711 & 0.5634 \\
\hline Pará & 11,847 & 364 & 189 & 0.626 \\
\hline Paraíba & 6,739 & 277 & 170 & 0.6139 \\
\hline Paraná & 19,218 & 1.056 & 418 & 0.5416 \\
\hline Pernambuco & 17,750 & 465 & 296 & 0.6366 \\
\hline Piauí & 6,903 & 149 & 75 & 0.6193 \\
\hline Rio de Janeiro & 22,457 & 809 & 505 & 0.6116 \\
\hline Rio Grande do Norte & 6,224 & 255 & 131 & 0.6074 \\
\hline Rio Grande do Sul & 20,682 & 822 & 385 & 0.5472 \\
\hline Rondônia & 3,530 & 95 & 71 & 0.5686 \\
\hline Roraima & 1,403 & 51 & 12 & 0.6398 \\
\hline Santa Catarina & 11,049 & 654 & 254 & 0.4942 \\
\hline São Paulo & 56,623 & 3.757 & 1.348 & 0.5768 \\
\hline Sergipe & 2,688 & 92 & 67 & 0.6288 \\
\hline Tocantins & 2,377 & 130 & 52 & 0.6099 \\
\hline
\end{tabular}

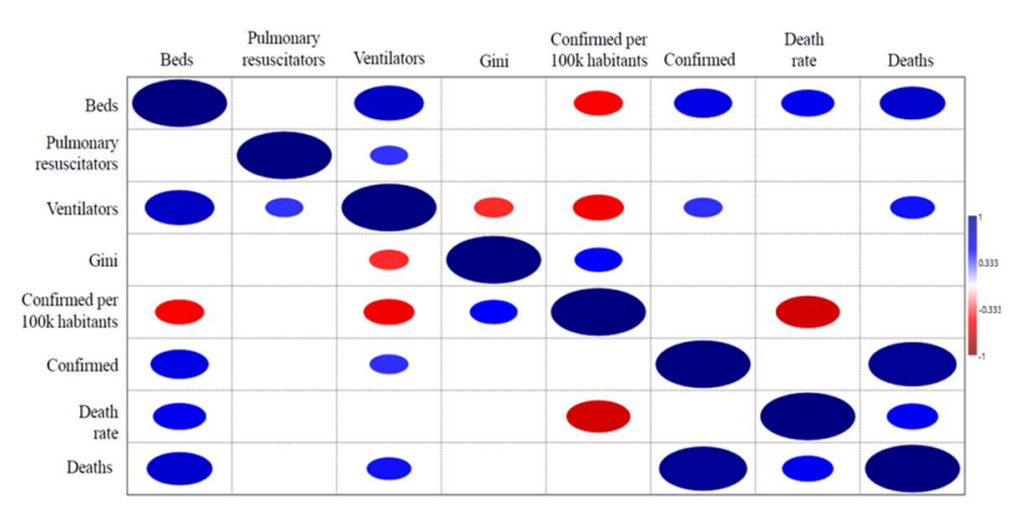

Fig. 6: Spearman's rank correlation coefficients (SRCC) between deaths, confirmed cases, deaths rate, confirmed per $100 \mathrm{k}$ habitants, health infrastructure and Gini coefficient.

The Gini coefficient had negative correlation with lung ventilators and positive correlation with confirmed cases per 100k habitants, therefore, States with higher social inequality had lower availability to adequate health equipment and consequently more deaths. This result corroborates with the obtained by Demenech et al. (2020), verifying that socioeconomic inequality explains the differences in the effect of the pandemic between states. Socioeconomic inequality places have greater exposure to the virus and susceptibility to disease, and less ability to take preventive measures and recovery. therefore. greater contagion and death cases (DEMENECH et al., 2020).

Confirmed cases per 100k inhabitants (Fig. 6) showed a negative correlation with both hospital beds and lung ventilators and positive correlation with Gini coefficient and death rate. In this context, the access to health infrastructure changes unequivocally in the different regions of Brazil, possibly because better material and institutional infrastructure is observed in the southeast and south regions, leading to greater opportunities for coping with contagion cases. Garcia et al. (2020) explain that the diversity in strategies and local responses to health care for the pandemic is due to the lack of coordination by both National and State executives. which means that poorer States struggle more with the effects of the COVID-19 (GARCIA et al., 2020). This is because there is less preparation in infrastructure in places with socioeconomic inequality, presenting higher numbers of vulnerable populations with low income, which can only access the SUS, with 
five times fewer beds compared to the private system (PIRES et al., 2020). Additionally, in Brazil only $94 \%$ of the poor population has no private health plan while for the richer population only $36 \%$ has no private health plan, making it necessary to take government decisions that expand measures at the level of infrastructure or social isolation in places with higher poverty (PIRES et al., 2020). For example, in the research of Thomé et al. (2020) for the city of São Paulo, places with lower socioeconomic level presented greater chronic diseases risk factors, less access to self-care resources and health services. in which the number of deaths by COVID19 was higher (THOMÉ et al., 2020).

\section{CONCLUSIONS}

GIS are key tools to map SARS-CoV-2 in Brazil, and the relationship between Gini Coefficient and health infrastructure such as number of hospital beds, pulmonary ventilators and resuscitators, factors that affect the dynamics of the pandemic and allow adequate decision making in the health sector.

The analysis from different contexts showed the expansion of SARS-CoV-2 disease in the regions and Brazil. Currently, the pandemic affects the entire Brazilian territory, mainly the southeast and northeast regions, characterized by the rapid expansion of the number of confirmed cases.

ACKNOWLEDGMENTS: We would like to thank to the IBGE (Instituto Brasileiro de Geografia e Estatistica), Datasus and Ministry of Health (Brazil) for the data availability.

\section{REFERENCES}

ANSELIN, L.. Spatial analytical perspectives on GIS. The Moran Scatterplot as an ESDA Tool to Assess Local Instability in Spatial Association. London: Taylor and Francis, 1996.

ANSELIN, L.. Local Indicators of Spatial Association-LISA. Geographical Analysis, v.27, n.2, p.93-115, 1995.

ANSELIN, L.. Thirty years of spatial econometrics. Papers on Regional Science, v.89, n.1, p.3-25, 2010.

AUGUSTA, C.; DEARDONB, R.; TAYLOR, G.. Deep learning for supervised classification of spatial epidemics. Spatial and Spatio-temporal Epidemiology, v.29, p.187-198, 2018.

BARRETO, M. L.; BARROS, A. J. D.; CARVALHO, M. S.; CODEÇO, C. T.; HALLAL, P. R. C.; MEDRONHO, R. A.; STRUCHINER, C. J.; VICTORA, C. G.; WERNECK, G. L.. What is urgent and necessary to inform policies to deal with the COVID-19 pandemic in Brazil? Revista Brasileira de Epidemiologia, v.23, n.E200032, p.1-4, 2020. DOI: http://doi.org/10.1590/1980-549720200032

BARTIER, P. M.; KELLER, C. P.. Multivariate interpolation to incorporate thematic surface data using inverse distance weighting (IDW). Computers \& Geosciences, v.22, n.7, p.795-799, 1996.

CÂMARA, G.; CARVALHO, M. S.; CRUZ, P. G.; CORREA, V.. Análise espacial de áreas. In: Análise espacial de dados geográficos. 2004. p.1-43.
CAMPOS, J. M. P.; SILVEIRA, E. F.; PÉRICO, E.. Analysis of sustainability in Rio Grande do Sul : a spatio-temporal application of the sustainability barometer. Revista IberoAmericana de Ciências Ambientais, v.12, n.1, p.471-483, 2021. DOI: http://doi.org/10.6008/CBPC21796858.2021.001.0038

CHEN, Z.; ZHANG, W.; LU, Y.; GUO, C.; GUO, Z.; LIAO, C.; ZHANG, X.; ZHANG, Y.; HAN, X.; LI, Q.; LU, J.. From SARS-CoV to Wuhan 2019-nCoV Outbreak : Similarity of Early Epidemic and Prediction of Future Trends. The Preprint Server for Biology, 2020. DOI: http://doi.org/10.1101/2020.01.24.919241

CORDES, J.; CASTRO, M. C.. Spatial and Spatio-temporal Epidemiology Spatial analysis of COVID-19 clusters and contextual factors in New York City. Spatial and Spatiotemporal Epidemiology, v.34, p.100355, 2020.

CUADROS, D. F.; XIAO, Y.; MUKANDAVIRE, Z.; CORREAAGUDELO, E.; HERNÁNDEZ, A.; KIM, H.; MACKINNON, N. J.. Spatiotemporal transmission dynamics of the COVID-19 pandemic and its impact on critical healthcare capacity. Health and Place, v.64, n.102404, 2020.

DEMENECH, L. M.; DUMTH, S. C.; VIEIRA, M. E. C. D.; NEIVASILVA, L.. Income inequality and risk of infection and death by COVID-19 in Brazil. Revista Brasileira de Epidemiologia, v.23, n.E200095, 2020. DOI: http://doi.org/10.1590/1980$\underline{549720200095}$ 
ELAVARASAN, R. M.; PUGAZHENDHI, R.. Restructured society and environment: A review on potential technological strategies to control the COVID-19 pandemic. Science of the Total Environment, v.725, p.138858, 2020.

FIGUEIREDO, D.; FERNANDES, A.; SILVA, L.; BORBA, L.; ROCHA, E.; HENRIQUE, D.. COVID-19 em dados: Brasil em perspectiva comparada. Rio de Janeiro: Universidade Federal do Rio de Janeiro, 2020.

GARCIA, L. P.; TRAEBERT, J.; BOING, A. C.; SANTOS, G. F. Z.; PEDEBÔS, L. A.; d'ORSI E.; PRADO, P. I.; VERAS, M. A. S. M.; BOAVA, G.; BOING, A. F.. The potential spread of Covid-19 and government decision-making: a retrospective analysis in Florianópolis, Brazil. Revista Brasileira de Epidemiologia, v.23, n.E200091, 2020. DOI: http://doi.org/10.1590/1980549720200091

JIMÉNEZ, C. L. V.. Epidemias y pandemias: una realidad para el siglo XXI. Un mundo y una salud. Revista Lasallista de Investigación, v.10, n.1, p.7-8, 2013.

LI, Q. et al. Early Transmission Dynamics in Wuhan, China, of Novel Coronavirus-Infected Pneumonia. New England Journal of Medicine, v.382, p.1199-1207, 2020. DOI: http://doi.org/10.1056/NEJMoa2001316

MACEDO, Y. M.; ORNELLAS, J. L.. COVID - 19 no Brasil: o que se espera para população subalternizada?. Revista Encantar - Educação, Cultura e Sociedade, v.2, p.1-10, 2020.

MARQUES, A. J.. Aplicações de técnicas de autocorrelação espacial para avaliação da organização das habitações nas mesorregiões do estado do Paraná. Observatorium: Revista Eletrônica de Geografia, v.1, n.3, p.89-105, 2018.

MATTOS, R.; MEREDES NETO, R.; CARVALHO, M. M. B.; DAVID, H. M. S. L.; ACIOLI, S.; FARIA, M. G. A.. Epidemiologia, políticas públicas e pandemia de Covid-19 : o que esperar no Brasil?. Revista Enfermagem UERJ, v.28, p.49570, 2020. DOI: http://doi.org/10.12957/reuerj.2020.49570

MCKIBBIN, W.; FERNANDO, R.. The Global Macroeconomic Impacts of COVID-19 : Seven Scenarios. Centre for Applied Macroeconomic Analysis, v.20, n.2, p.1-30, 2020. DOI: http://doi.org/10.1162/asep a 00796

PAN, Y.; GUAN, H.; ZHOU, S.; WANG, Y.; LI, Q.; ZHU, T.; HU, Q.; XIA, L.. Initial CT findings and temporal changes in patients with the novel coronavirus pneumonia (2019nCoV): a study of 63 patients in Wuhan, China. European radiology, p.1-4, 2020. DOI: http://doi.org/10.1007/s00330020-06731-x

PIRES, L. N.; CARVALHO, L.; XAVIER, L. L.. COVID-19 e desigualdade: a distribuição dos fatores de risco no Brasil. Experiment Findings, 2020. DOI: http://doi.org/10.13140/RG.2.2.27014.73282

ROCHA FILHO, T. M. R.; SANTOS, F. S. G.; GOMES, V. B.; ROCHA, T. A. H.; CRODA, J. H. R.; RAMALHO, W. M.; ARAÚJO, W. N.. Expected impact of COVID-19 outbreak in a major metropolitan area in Brazil. MedRxiv, p.1-11, 2020. DOI: http://doi.org/10.1101/2020.03.14.20035873
RODRIGUEZ-MORALES, A. J.; GALLEGO, V.; ESCALERAANTEZANA, J. P.; MÉNDEZ, C. A.; ZAMBRANO, L. I.; FRANCOPAREDES, C.; SUÁREZ, J. A.; RODRIGUEZ-ENCISO, H. D.; BALBIN-RAMON, G. J.; SAVIO-LARRIERA, E.; RISQUEZ, A.; CIMERMAN, S.. COVID-19 in Latin America: the implications of the first confirmed case in Brazil. Travel Medicine and Infectious Disease, v.35, n.101613, 2020. DOI: http://doi.org/10.1016/j.tmaid.2020.101613

ROSENKRANTZ, L.; SCHUURMAN, N.; BELL, N.; AMRAM, O. The need for GIScience in mapping COVID-19. Health and Place, v.67, p.102389, 2020. DOI: http://doi.org/10.1016/j.healthplace.2020.102389

ROTHE, C.; SCHUNK, M.; SOTHMANN, P.; BRETZEL, G.; FOESCHL, G.; WALLRAUCH, C.; ZIMMER, T.; THIEL, V.; JANKE, C.; GUGGEMOS, W.; SEILMAIER, M.; DROSTEN. C.; VOLLMAR, P.; ZWIRGLMAIER, K. ZANGE, S.; WOLFEL, R.; HOELSCHER, M.. Transmission of 2019-nCoV Infection from an Asymptomatic Contact in Germany. New England Journal of Medicine, v.382, p.970-971, 2020. DOI: http://doi.org/10.1056/NEJMc2001468

SAHIN, A. R.; ERDOGAN, A.; AGAOGLU, P. M.; DINERI, Y.; CAKIRCI, A. Y.; SENEL, M. E.; OKYAY, R. A.; TADOGAN, A. M. 2019 Novel Coronavirus (COVID-19) Outbreak: A Review of the Current Literature. EJMO, v.4, n.1, p.1-7, 2020. DOI: http://doi.org/10.14744/ejmo.2020.12220

SALDIVA, P.. Vida Urbana e Saúde: os desafios dos habitantes das metrópoles. 2018.

SOHRABI, C.; ALSAFI, Z.; O'NEILL, N.; KHAN, M.; KERWAN, A.; AL-JABIR, A.; LOSIFIDIS, C.; AGHA, R.. World Health Organization declares global emergency: a review of the 2019 novel coronavirus (COVID-19). International Journal of Surgery, v.76, p.71-76, 2020. DOI: http://doi.org/10.1016/j.ijsu.2020.02.034

THOMÉ, B.; REZENDE, L. F. M.; SCHVEITZER, M. C.; MONTEIRO, C. N.; GOLDBAUM, M.. Differences in the prevalence of risk factors for severe COVID-19 across regions of São Paulo City. Revista Brasileira de Epidemiologia, v.23, n.E200087, p.1-6, 2020. DOI: http://doi.org/10.1590/1980549720200087

TRUONG, P. N.; STEIN, A.. Spatial and Spatio-temporal Epidemiology Model-based small area estimation at two scales using Moran's spatial filtering. Spatial and Spatiotemporal Epidemiology, v.31, p.100303, 2019.

VISCONTI, G. R.; SANTOS, M. C.. Região Sudeste: recuperando para desenvolver. In: LEAL, C. F. C. et al. Um olhar territorial para o desenvolvimento: Sudeste. Rio Janeiro: Banco Nacional de Desenvolvimento Econômico e Social, 2015. p.192-205.

ZHOU, C.; SU, F.; PEI, T.; ZHANG, A.; DU, Y.; LUO, B.; CAO, Z.; WANG, J.; YAN, W.; ZHU, Y.; SONG, C.; CHEN, J.; XU, J.; LI, F.; MA, T.; JIANG, L.; YAN, F.; YI, J.; HU, Y.; LIAO, Y.; XIAO, H. COVID-19: Challenges to GIS with Big Data. Geography and Sustainability, v.1, n.1, p.77-87, 2020. DOI: http://doi.org/10.1016/i.geosus.2020.03.005

A CBPC - Companhia Brasileira de Produção Científica (CNPJ: 11.221.422/0001-03) detém os direitos materiais desta publicação. Os direitos referem-se à publicação do trabalho em qualquer parte do mundo, incluindo os direitos às renovações, expansões e disseminações da contribuição, bem como outros direitos subsidiários. Todos os trabalhos publicados eletronicamente poderão posteriormente ser publicados em coletâneas impressas sob coordenação da Sustenere Publishing, da Companhia Brasileira de Produção Cientifica e seus parceiros autorizados. Os (as) autores (as) preservam os direitos autorais, mas não têm permissão para a publicação da contribuição em outro meio, impresso ou digital, em português ou em tradução. 